\title{
A 34-Marker Panel for Imaging Mass Cytometric Analysis of Human Snap-Frozen Tissue
}

\author{
Nannan Guo ${ }^{1}$, Vincent van Unen ${ }^{1,2}$, Marieke E. ljsselsteijn ${ }^{3}$, Laura F. Ouboter ${ }^{4}$, \\ Andrea E. van der Meulen ${ }^{4}$, Susana M. Chuva de Sousa Lopes ${ }^{5}$, \\ Noel F. C. C. de Miranda ${ }^{3}$, Frits Koning ${ }^{1 * t}$ and $\mathrm{Na} \mathrm{Li}^{1,6 * t}$
}

${ }^{1}$ Immunohematology and Blood Transfusion, Leiden University Medical Center, Leiden, Netherlands, ${ }^{2}$ Institute for Immunity, Transplantation and Infection, Stanford University, Stanford, CA, United States, ${ }^{3}$ Pathology, Leiden University Medical Center, Leiden, Netherlands, ${ }^{4}$ Gastroenterology, Leiden University Medical Center, Leiden, Netherlands, ${ }^{5}$ Anatomy, Leiden University Medical Center, Leiden, Netherlands, ${ }^{6}$ Key Laboratory of Zoonoses Research, Ministry of Education, Institute of Zoonoses, College of Veterinary Medicine, Jilin University, Changchun, China

OPEN ACCESS

Edited by:

Christoph Mueller

University of Bern, Switzerland

Reviewed by:

Ruben Casanova,

University of Zurich, Switzerland Diane Bimczok,

Montana State University, United States

*Correspondence:

Frits Koning

f.koning@/umc.n

$\mathrm{NaLi}$

vetlina2013@126.com

†These authors have contributed equally to this work

Specialty section: This article was submitted to

Mucosal Immunity,

a section of the journal

Frontiers in Immunology

Received: 04 April 2020 Accepted: 05 June 2020

Published: 16 July 2020

Citation:

Guo N, van Unen V, ljsselsteijn ME,

Ouboter $L F$, van der Meulen $A E$,

Chuva de Sousa Lopes SM, de Miranda NFCC, Koning F and Li N (2020) A 34-Marker Panel for Imaging Mass Cytometric Analysis of Human Snap-Frozen Tissue.

Front. Immunol. 11:1466. doi: 10.3389/fimmu.2020.01466
Imaging mass cytometry (IMC) is able to quantify the expression of dozens of markers at sub-cellular resolution on a single tissue section by combining a novel laser ablation system with mass cytometry. As such, it allows us to gain spatial information and antigen quantification in situ, and can be applied to both snap-frozen and formalin-fixed, paraffin-embedded (FFPE) tissue sections. Herein, we have developed and optimized the immunodetection conditions for a 34-antibody panel for use on human snap-frozen tissue sections. For this, we tested the performance of 80 antibodies. Moreover, we compared tissue drying times, fixation procedures and antibody incubation conditions. We observed that variations in the drying times of tissue sections had little impact on the quality of the images. Fixation with methanol for $5 \mathrm{~min}$ at $-20^{\circ} \mathrm{C}$ or $1 \%$ paraformaldehyde (PFA) for $5 \mathrm{~min}$ at room temperature followed by methanol for $5 \mathrm{~min}$ at $-20^{\circ} \mathrm{C}$ were superior to fixation with acetone or PFA only. Finally, we observed that antibody incubation overnight at $4^{\circ} \mathrm{C}$ yielded more consistent results as compared to staining at room temperature for $5 \mathrm{~h}$. Finally, we used the optimized method for staining of human fetal and adult intestinal tissue samples. We present the tissue architecture and spatial distribution of the stromal cells and immune cells in these samples visualizing blood vessels, the epithelium and lamina propria based on the expression of $\alpha$-smooth muscle actin $(\alpha-S M A), E-C a d h e r i n$ and Vimentin, while simultaneously revealing the colocalization of $T$ cells, innate lymphoid cells (ILCs), and various myeloid cell subsets in the lamina propria of the human fetal intestine. We expect that this work can aid the scientific community who wish to improve IMC data quality.

\section{Keywords: imaging mass cytometry, IMC, snap-frozen tissue sections, human intestine, mass cytometry}

\section{INTRODUCTION}

In recent years, the development of a variety of single-cell technologies increased recognition of cellular heterogeneity both in physiological and pathological contexts. Single-cell technologies based on RNA sequencing and mass cytometry (CyTOF) have been utilized to investigate cellular heterogeneity and identify novel cellular subsets $(1,2)$, and to discover biomarkers with clinical 
value (3). Single-cell mass cytometry employs antibodies conjugated to stable metal isotopes, mostly from the lanthanide series, and is currently able to analyze over 40 different markers simultaneously, allowing an in-depth analysis of immune subsets. However, when analyzing cells isolated from tissue, no spatial information on cell-cell interactions within the tissue is obtained. Imaging mass cytometry (IMC) is an extension of mass cytometry, which couples a laser ablation system with a mass cytometer (4) and therefore has the ability to analyze up to 40 markers in a single tissue section. As such, IMC has the potential to simultaneously characterize the composition of the immune compartment, the spatial relationship between immune cells and stromal cells, and the interactions among immune subsets in tissue sections of choice.

Classical immunohistochemistry or immunofluorescence techniques for cell and tissue imaging provide high spatial resolution at subcellular resolution (5), however, these suffer from limitations including the limited number of markers that can be used simultaneously and tissue auto-fluorescence (6). IMC does not suffer from background interference as the read-out is provided by the presence of rare earth metals conjugated to antibodies which considerably increase the multiplexing capacity. The IMC laser system ablates the tissue in segments of one by one micrometer which are directed into the mass cytometer using a gas stream, then atomized and ionized followed by determination of the metal-isotope ion content in the on-line time-of-flight mass analyzer (7). IMC thus offers significant advantages over the current imaging standards. However, care should be taken with the design of the antibody panels as there can be spillover detectable from one mass channel into other channels due to isotopic impurities of the rare metals, usually below $3 \%$ (8), and a method has been developed to reduce spillover artifacts and improve the generation of high-quality data (9). IMC is rapidly becoming widespread as it can aid both basic research and clinical practice (10, 11).

However, the use of IMC is still challenging due to the limited experience with the design and validation of antibody panels and the best tissue processing procedures and staining procedures compatible with the dozens of antibodies that are applied simultaneously, especially with respect to snap-frozen tissue as most experience to date is with formalin-fixed paraffinembedded (FFPE) tissue.

Here, we developed a 34 antibody panel for the analysis of snap-frozen tissues by IMC, which contains immune lineage and additional markers to distinguish immune cell subsets in addition to structural markers to reveal tissue organization. This panel can be used to obtain comprehensive spatial information on interactions both between immune cell subsets and between immune cell subsets and stromal components. Furthermore, we developed an optimized fixation and antibody incubation protocol to improve the IMC data quality. We anticipate that this optimized methodology will give guidance to the scientific community in using IMC on snap-frozen tissue to generate high-quality images.

\section{MATERIALS AND METHODS}

\section{Tissue Samples}

Fetal tissues were obtained from elective abortions with informed consent. The adult intestinal samples were collected from patients undergoing routine diagnostic endoscopies. Approval by the medical ethical commission of the Leiden University Medical Center (protocol P08.087) was obtained in accordance with the local ethical guidelines and the Declaration of Helsinki. The adult and fetal intestinal samples were embedded in optimal cutting temperature compound, snap-frozen in isopentane (VWR) and stored at $-80^{\circ} \mathrm{C}$.

\section{Antibody Validation and Conjugation}

Antigens were selected based on previously published singlecell mass cytometry and single-cell RNA sequencing data on the human fetal intestinal samples $(1,12,13)$. Antibodies used for IMC are listed in Table 1. 16 of the 34 antibodies used in the current panel were directly purchased from Fluidigm, which were already conjugated with metals. For the remaining 18 antibodies, BSA-free and carrier-free formulations of antibodies were purchased from different suppliers and initially tested for performance by immunohistochemical staining (IHC) on human fetal intestine and tonsil. Subsequently, antibodies with an appropriate signal intensity were conjugated to lanthanide metals using the MaxPar Antibody Labeling Kit (Fluidigm) following the manufacturer's instructions. Post-conjugation, all antibodies were eluted in $100 \mu \mathrm{l} \mathrm{W}$-buffer (Fluidigm) and 100 $\mu l$ antibody stabilizer buffer (Candor Bioscience, Wangen im Allgäu, Germany) supplemented with $0.05 \%$ sodium azide.

\section{Optimization of IMC Immunostaining Protocol}

Here, three variables were tested: (1) Drying condition of freshly prepared snap-frozen tissue sections; (2) Fixation procedures; and (3) Antibody staining conditions. For drying we compared $3 \mathrm{~min}$ at room temperature (RT) with $30 \mathrm{~min}$ at RT, and $1 \mathrm{~h}$ at $60^{\circ} \mathrm{C}$. For fixation we compared methanol for $5 \mathrm{~min}$ at $-20^{\circ} \mathrm{C}$, with $1 \%$ PFA for $5 \mathrm{~min}$ at RT, 1\% PFA for $5 \mathrm{~min}$ at RT followed by methanol for $5 \mathrm{~min}$ at $-20^{\circ} \mathrm{C}$, acetone for $10 \mathrm{~min}$ at RT, and $4 \%$ PFA for $5 \mathrm{~min}$ at RT. For antibody incubation we compared $5 \mathrm{~h}$ at RT with overnight at $4^{\circ} \mathrm{C}$. We utilized one frozen sample to test each condition and a single antibody mix to stain all section slides. An overview of the experimental set up for the testing of the various conditions is provided in Table 2. All comparisons were performed simultaneously. The following is a step-by-step staining procedure of the IMC procedure utilizing snap-frozen tissue.

\section{Material}

- Five micrometer fresh snap-frozen sections on silane-coated glass slides (VWR)

- Paraformaldehyde (1\%, 4\%)

- Methanol

- Acetone

- Superblock solution (Thermo Fisher Scientific) 
TABLE 1 | The 34-marker panel for imaging mass cytometry on snap-frozen tissue.

\begin{tabular}{|c|c|c|c|c|c|c|}
\hline & Antigen & Tag & Clone & Supplier & Cat. & Dilution \\
\hline 1 & CD45 & $89 Y$ & HI30 & Flui & 3089003В & $1 / 50$ \\
\hline 2 & D2-40 & $115 \ln$ & D2-40 & BioL & 916606 & $1 / 50$ \\
\hline 3 & FOXp3 & $142 \mathrm{Nd}$ & D608R & CST & 12653BF & $1 / 50$ \\
\hline 4 & CD69 & $144 \mathrm{Nd}$ & FN50 & Flui & 3144018B & $1 / 50$ \\
\hline 5 & CD4 & $145 \mathrm{Nd}$ & RPA-T4 & Flui & 3145001B & $1 / 50$ \\
\hline 6 & CD8a & $146 \mathrm{Nd}$ & RPA-T8 & Flui & 3146001B & $1 / 50$ \\
\hline 7 & Collagen I & $147 \mathrm{Sm}$ & Polyclonal & Millipore & AB758 & $1 / 100$ \\
\hline 8 & $\alpha-S M A$ & $148 \mathrm{Nd}$ & $1 \mathrm{~A} 4$ & CST & CST5685BF & $1 / 200$ \\
\hline 9 & CD31 & 149Sm & $89 \mathrm{C} 2$ & CST & CST3528BF & $1 / 100$ \\
\hline 10 & E-Cadherin & $150 \mathrm{Nd}$ & 24 E 10 & CST & CST3195BF & $1 / 50$ \\
\hline 11 & CD123 & 151Eu & $6 \mathrm{H} 6$ & Flui & 3151001B & $1 / 50$ \\
\hline 12 & CD7 & 153Eu & CD7-6B7 & Flui & 3153014B & $1 / 100$ \\
\hline 13 & CD163 & $154 \mathrm{Sm}$ & $\mathrm{GHI} / 61$ & Flui & 3154007B & $1 / 100$ \\
\hline 14 & CD103 & $155 \mathrm{Gd}$ & EPR4166 & Abcam & ab221210 & $1 / 50$ \\
\hline 15 & CD127 & $156 \mathrm{Gd}$ & R34.34 & Beckman & 18LIQ494 & $1 / 50$ \\
\hline 16 & CD122 & $158 \mathrm{Gd}$ & TU27 & BioL & 339015 & $1 / 25$ \\
\hline 17 & CD68 & 159Tb & KP1 & Flui & 3159035D & $1 / 200$ \\
\hline 18 & CD5 & $160 \mathrm{Gd}$ & UCHT2 & BioL & 300627 & $1 / 25$ \\
\hline 19 & CD20 & 161Dy & $\mathrm{H} 1$ & Flui & 3161029D & $1 / 50$ \\
\hline 20 & CD11c & 162Dy & Bu15 & Flui & 3162005B & $1 / 50$ \\
\hline 21 & CD45 & 163Dy & D9M81 & CST & 13917BF & $1 / 200$ \\
\hline 22 & CD161 & 164Dy & HP-3G10 & Flui & 3164009B & $1 / 50$ \\
\hline 23 & CD117 & $165 \mathrm{Ho}$ & 104D2 & BioL & 313202 & $1 / 50$ \\
\hline 24 & $\mathrm{Ki}-67$ & $166 \mathrm{Er}$ & D3B5 & CST & CST 9129BF & $1 / 200$ \\
\hline 25 & CD27 & $167 \mathrm{Er}$ & O323 & Flui & 3167002B & $1 / 50$ \\
\hline 26 & HLA-DR & $168 \mathrm{Er}$ & L243 & BloL & 307651 & $1 / 800$ \\
\hline 27 & CD45RA & 169Tm & HI100 & Flui & 3169008B & $1 / 100$ \\
\hline 28 & CD3 & 170Er & UCHT1 & Flui & 3170001B & $1 / 100$ \\
\hline 29 & CD28 & $171 \mathrm{Yb}$ & CD28.2 & BioL & 302937 & $1 / 50$ \\
\hline 30 & CD38 & $172 \mathrm{Yb}$ & HIT2 & Flui & 3172007B & $1 / 100$ \\
\hline 31 & CD45RO & 173Yb & UCHL1 & BioL & 304239 & $1 / 50$ \\
\hline 32 & CD57 & $174 \mathrm{Yb}$ & HNK-1/Leu-7 & Abcam & Ab212403 & $1 / 100$ \\
\hline 33 & Vimentin & 175Lu & D21H3 & CST & CST5741BF & $1 / 200$ \\
\hline 34 & CD56 & 176Yb & NCAM16.2 & Flui & 3176008B & $1 / 50$ \\
\hline
\end{tabular}

Flui, Fluidigm; CST, cell signaling technology; Biol, Biolegend.

- DPBS (Gibco)

- Wash buffer (DPBS supplemented with 0.05\% Tween and $1 \%$ BSA)

- Metal-conjugated antibodies (Table 1)

- Intercalator-Ir $(500 \mu \mathrm{M}$, Fluidigm)

- Milli-Q water

- Dako Pen (Thermo Fisher Scientific)

- Slide container, 5 slide capacity (VWR)

- Incubation chamber (humid, $4^{\circ} \mathrm{C}$ and RT).

\section{Stepwise Procedure for Immunodetection}

1. Cut the fresh frozen sections at $5 \mu \mathrm{m}$ and mount them on silane-coated glass slides
2. Dry the tissue sections for $3 \mathrm{~min}$ at RT, $30 \mathrm{~min}$ at $\mathrm{RT}$ or $1 \mathrm{~h}$ at $60^{\circ} \mathrm{C}$

3. Fix the tissue slides without shaking as mentioned above

4. Rinse the slides once, followed by washing the slides twice for $5 \mathrm{~min}$ in a container of 5 slide capacity with $25 \mathrm{ml}$ wash buffer

5. Rehydrate the slides for $5 \mathrm{~min}$ in container of 5 slide capacity with $25 \mathrm{ml}$ DPBS

6. Wash the slides for 5 min in container of 5 slide capacity with $25 \mathrm{ml}$ wash buffer

7. Use the Dako Pen to draw a circle around the tissue sections to create a barrier to contain the antibody solutions on the tissue sections

8. Apply $100 \mu \mathrm{l}$ superblock solution to each slide for $30 \mathrm{~min}$ at RT

9. Remove excess superblock solution by tapping on a tissue

10. Prepare the antibody cocktail by diluting the antibodies in wash buffer as described in Table 1

11. Add $100 \mu \mathrm{l}$ of the antibody cocktail to each section and incubate for $5 \mathrm{~h}$ at $\mathrm{RT}$ or overnight at $4^{\circ} \mathrm{C}$ in a humid chamber

12. After the incubation, wash the sections three times for $5 \mathrm{~min}$ in container of 5 slide capacity with $25 \mathrm{ml}$ wash buffer

13. Incubate the slides with $100 \mu 1$ 1:400 dilution of IntercalatorIr in DPBS for $30 \mathrm{~min}$ at RT

14. Rinse the slides once, wash the slides for $5 \mathrm{~min}$ in container of 5 slide capacity with $25 \mathrm{ml}$ wash buffer twice

15. Wash the slides for $1 \mathrm{~min}$ in container of 5 slide capacity with $25 \mathrm{ml}$ Milli-Q water

16. Dry the slides with an air flow

17. Store the slides at $4^{\circ} \mathrm{C}$ until ablation on Hyperion.

\section{Imaging Mass Cytometry Acquisition}

Tissue acquisition was performed on a Helios time-of-flight mass cytometer coupled to a Hyperion Imaging System (Fluidigm). All IMC operation was performed as described using the Hyperion Imaging System (Fluidigm). Briefly, after flushing the ablation chamber with helium, tissues were ablated by a UV-laser spotby-spot at a resolution of $1 \mu \mathrm{m}$ and a frequency of $200 \mathrm{~Hz}$. Regions of interest (ROIs) with $1,000 \mu \mathrm{m} \times 1,000 \mu \mathrm{m}$ were selected. We ablated $5 \sim 8$ ROIs for each tissue section. All raw data were analyzed for marker intensity based on the maximum signal threshold, defines at the 98th percentile of all pixels in a single ROI using the Fluidigm $\mathrm{MCD}^{\mathrm{TM}}$ viewer (v1.0.560.2). To distinguish the signal from background, we used the Fluidigm $\mathrm{MCD}^{\mathrm{TM}}$ viewer to visualize our data, and adjusted the Threshold Min values for each marker individually (between 1 and 2 for majority of immune markers and between 1 and 3 for structural markers) to eliminate background.

\section{RESULTS}

To develop the IMC antibody panel, we first evaluated the performance of an antibody panel previously developed for cell suspension mass cytometry (1). This revealed that 18 out of the 36 antibodies were suitable for IMC on snapfrozen tissue. Subsequently we continued to select additional antibodies to phenotype immune cells and visualize the tissue 
TABLE 2 | The experimental set up of the testing of the various conditions.

\begin{tabular}{|c|c|c|c|c|c|c|c|c|c|c|}
\hline \multirow[t]{2}{*}{ Slide Nr } & \multicolumn{3}{|c|}{ Slide drying } & \multicolumn{5}{|c|}{ Fixation } & \multicolumn{2}{|c|}{ Panel incubation } \\
\hline & $3 \mathrm{~min}$ & $30 \mathrm{~min}$ & $1 \mathrm{~h}$ & Methanol & $1 \%$ PFA & $1 \%$ PFA + methanol & Acetone & $4 \%$ PFA & $5 \mathrm{~h}$ at $\mathrm{RT}$ & Overnight at $4^{\circ} \mathrm{C}$ \\
\hline 1 & + & - & - & - & - & + & - & - & - & + \\
\hline 2 & - & + & - & + & - & - & - & - & - & + \\
\hline 3 & - & + & - & - & + & - & - & - & - & + \\
\hline 4 & - & + & - & - & - & + & - & - & - & + \\
\hline 5 & - & + & - & - & - & - & + & - & - & + \\
\hline 6 & - & + & - & - & - & - & - & + & - & + \\
\hline 7 & - & + & - & - & - & + & - & - & + & - \\
\hline $8^{*}$ & - & - & + & - & - & + & - & - & - & + \\
\hline
\end{tabular}

${ }^{\star}$ Conditions applied to slide \#8 represent the optimal staining protocol.

structure. All candidate antibodies which required in-house conjugation with metals were initially tested for performance by conventional immunohistochemistry (not shown). Based on this we selected antibodies that displayed a clear signalto-background ratio for potential inclusion in the final IMC antibody panel. In total, 80 antibodies were tested, 43 of which performed well on frozen sections. Table 2 lists the 34 antibodies that were finally chosen for inclusion into the IMC antibody panel. Supplementary Table 1 provides information on the performance of the 46 antibodies that were not included in the panel.

In order to ensure proper tissue adherence, we determined the influence of the time of drying for the freshly prepared tissue sections. We evaluated the staining obtained with each of the 34 antibodies on tissue sections that were either dried for 3 or $30 \mathrm{~min}$ at $\mathrm{RT}$, or for $1 \mathrm{~h}$ at $60^{\circ} \mathrm{C}$. Both visual inspection of the obtained images and comparison of the maximum signal threshold values for each antibody indicated that the staining intensity was comparable with all three drying conditions (Supplementary Figure 1A). We also observed that the signalto-background ratio was highly similar with the three tested conditions (Supplementary Figure 1B). Therefore, we conclude that the drying conditions tested are in principle all suitable for IMC on snap-frozen tissue sections.

As tissue fixation is required to preserve antigenic determinants in tissues we first evaluated the protocol provided by Fluidigm (14). However, we observed that acetone fixation did not yield satisfactory results with respect to the quality of both the nuclear staining and the antibody staining (not shown). Therefore, we proceeded to test additional fixation procedures to optimize signal intensity and signal-to- background ratio. We tested 5 conditions, using serial sections from a single tissue sample: methanol, 1\% PFA, 1\% PFA followed by methanol, acetone and 4\% PFA and evaluated the staining obtained with the 34 antibodies individually (Figures 1A,B). We observed that none of the tested fixation conditions yielded optimal results for all antibodies in the panel. As expected, we observed inadequate nuclear staining with acetone, incompatible with proper cell identification and cell segmentation analysis (Figure 1B). Moreover, comparison of the maximum signal threshold values for each antibody indicated that several markers performed relatively poor when either 1 or 4\% PFA were used for fixation (e.g., CD161, CD163, CD3, CD7, CD68, HLA-DR, Vimentin, $\alpha$-SMA) while fixation with methanol or $1 \%$ PFA followed by methanol yielded stronger signals. In addition, we observed higher background staining for immune markers (e.g., antiCD45, clone HI30, and anti-CD3, Figure 1B) in both the acetone and PFA-only samples while the methanol and 1\% PFA followed by methanol fixed samples provided superior antibody staining results (Figure 1B). However, the nuclear staining in the lamina propria of the intestine was slightly better in the PFA + methanol samples. Based on these observation, we conclude that fixation with methanol or with the combination of $1 \%$ PFA followed by methanol are both preferred for IMC immunodetection of snap-frozen samples.

As staining quality is strongly influenced by duration of and temperature during antibody incubation (15), we tested two different incubation conditions for the individual antibodies in the 34-marker panel: $5 \mathrm{~h}$ at $\mathrm{RT}$ or overnight at $4^{\circ} \mathrm{C}$, after which the signal intensity and specificity were assessed by IMC for each antibody. We also determined the maximum signal threshold for all antibodies within several ROIs to compare the staining intensity between the two conditions. We found that the staining intensity of many antibodies were similar under both conditions, while a number of markers performed better either at $4{ }^{\circ} \mathrm{C}$ (anti-CD20 and anti-E-Cadherin) or at RT (anti-CD45_1, and anti-CD45RA) (Figure 2A). However, we observed more variation in the maximum threshold values for the evaluated ROIs stained at RT compared to $4^{\circ} \mathrm{C}$ and for many antibodies higher background was observed at RT. For example, anti- $\alpha$-SMA, anti-E-Cadherin and anti-CD7 yielded higher specific staining and lower background after overnight incubation at $4{ }^{\circ} \mathrm{C}$ compared to a $5 \mathrm{~h}$ incubation at RT while several other antibodies performed equally well at both test conditions as observed with anti-CD45RA (Figure 2B). As incubation at $4^{\circ} \mathrm{C}$ yielded generally better results we decided to use this condition for validation of the full antibody panel.

We next applied the optimized protocol in which the tissue section was dried for $1 \mathrm{~h}$ at $60^{\circ} \mathrm{C}$, followed by fixation with 

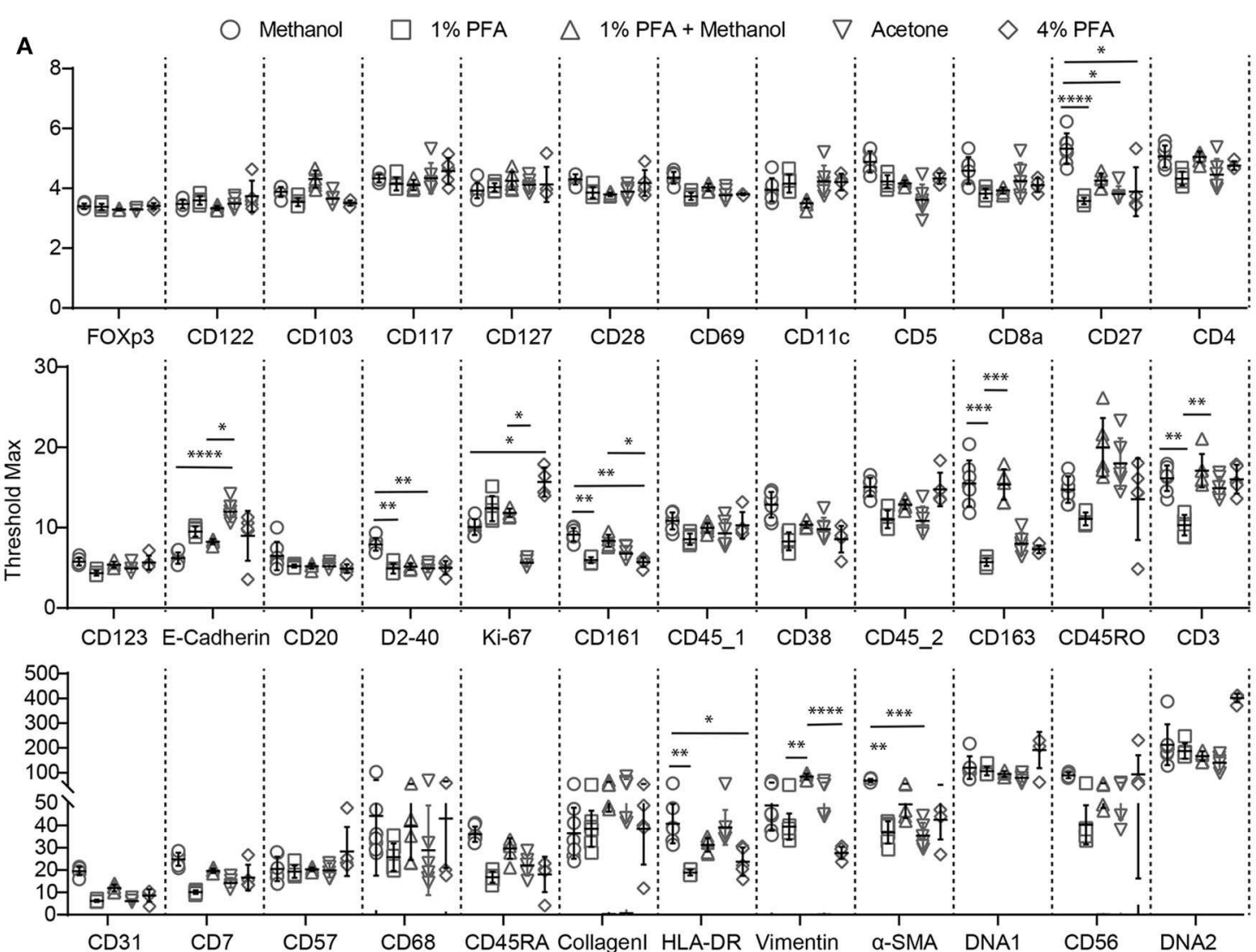

B
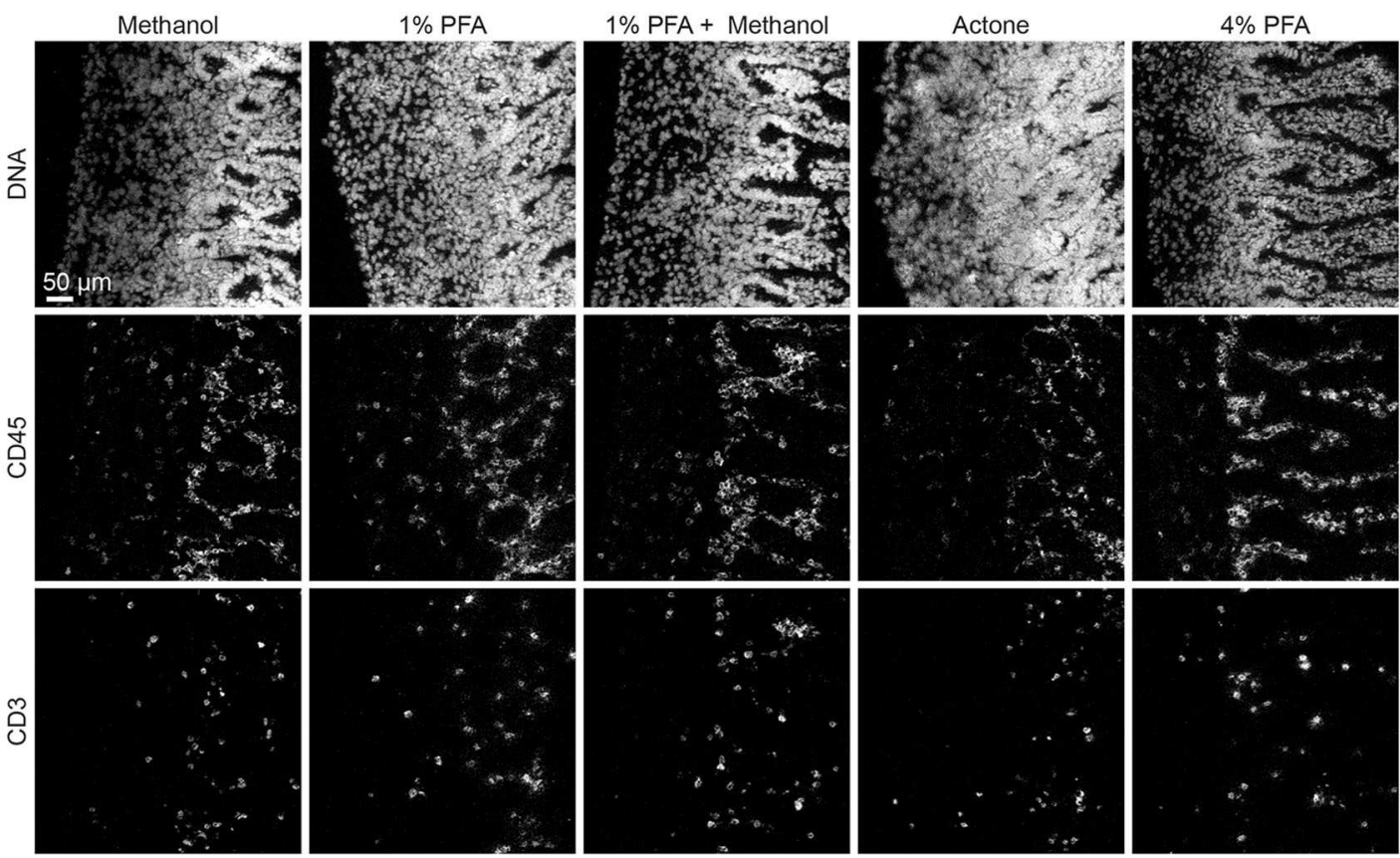

FIGURE 1 | Comparison of antibody and nuclear staining between different fixation procedures for IMC within a single tissue block. (A) Comparison of the staining intensity of each antibody depending on the fixation conditions, based on the maximum signal threshold in MCD ${ }^{\mathrm{TM}}$ viewer. Black bars indicate median \pm IQR. Each gray dot represents an individual ROI. ${ }^{\star} P<0.05$, ${ }^{\star \star} P<0.01$, ${ }^{\star \star \star} P<0.001$ and ${ }^{\star \star \star \star} P<0.0001$ by Kruskal-Wallis test with Dunn's test for multiple comparisons. (B) The markers CD45 and CD3 are representative for the variations observed with the tested incubation conditions. The minimum signal threshold of 2 dual count was set for the nuclear staining, while that was 1.5 for the immune markers. 


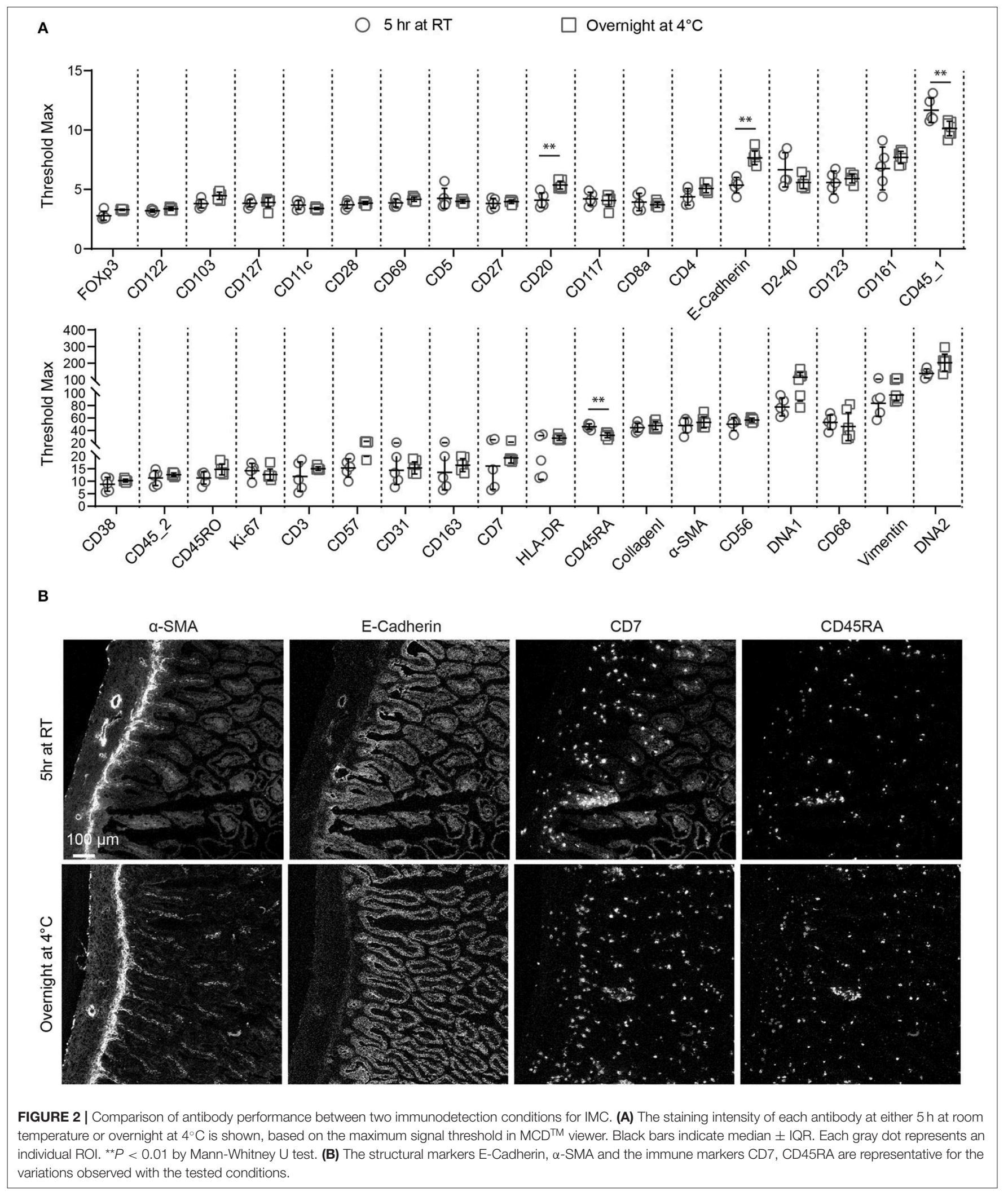


PFA + methanol and antibody panel incubation overnight at $4^{\circ} \mathrm{C}$ to stain a human fetal intestinal sample with the full 34-antibody panel which included structural tissue markers (Collagen I, E-Cadherin, $\alpha$-SMA, Vimentin and
D2-40) as well as markers to identify various cell types within the lymphoid and myeloid compartments (Table 1). Moreover, the panel allows for the visualization of additional features such as naïve and memory states (CD45RA/RO), cell

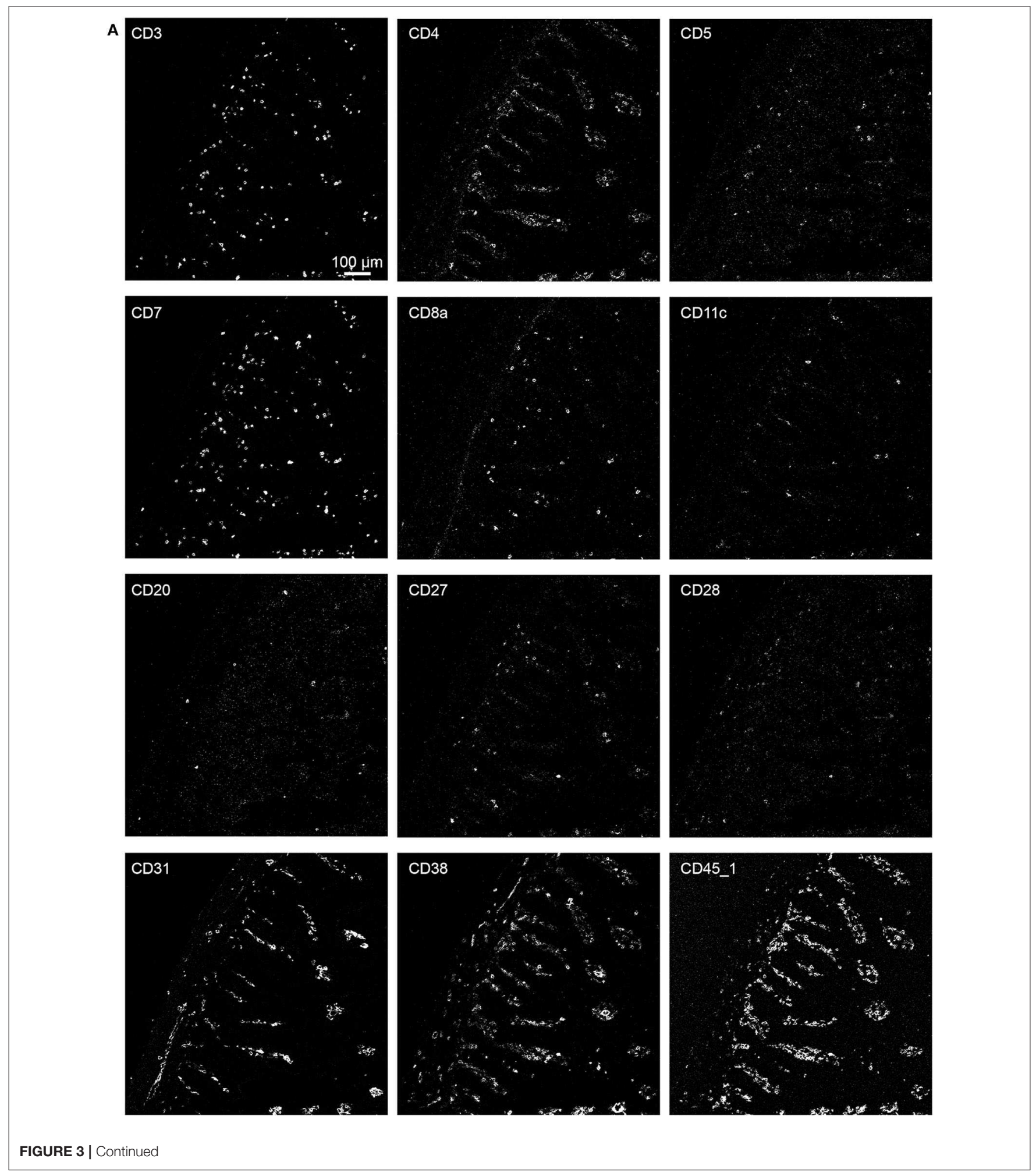



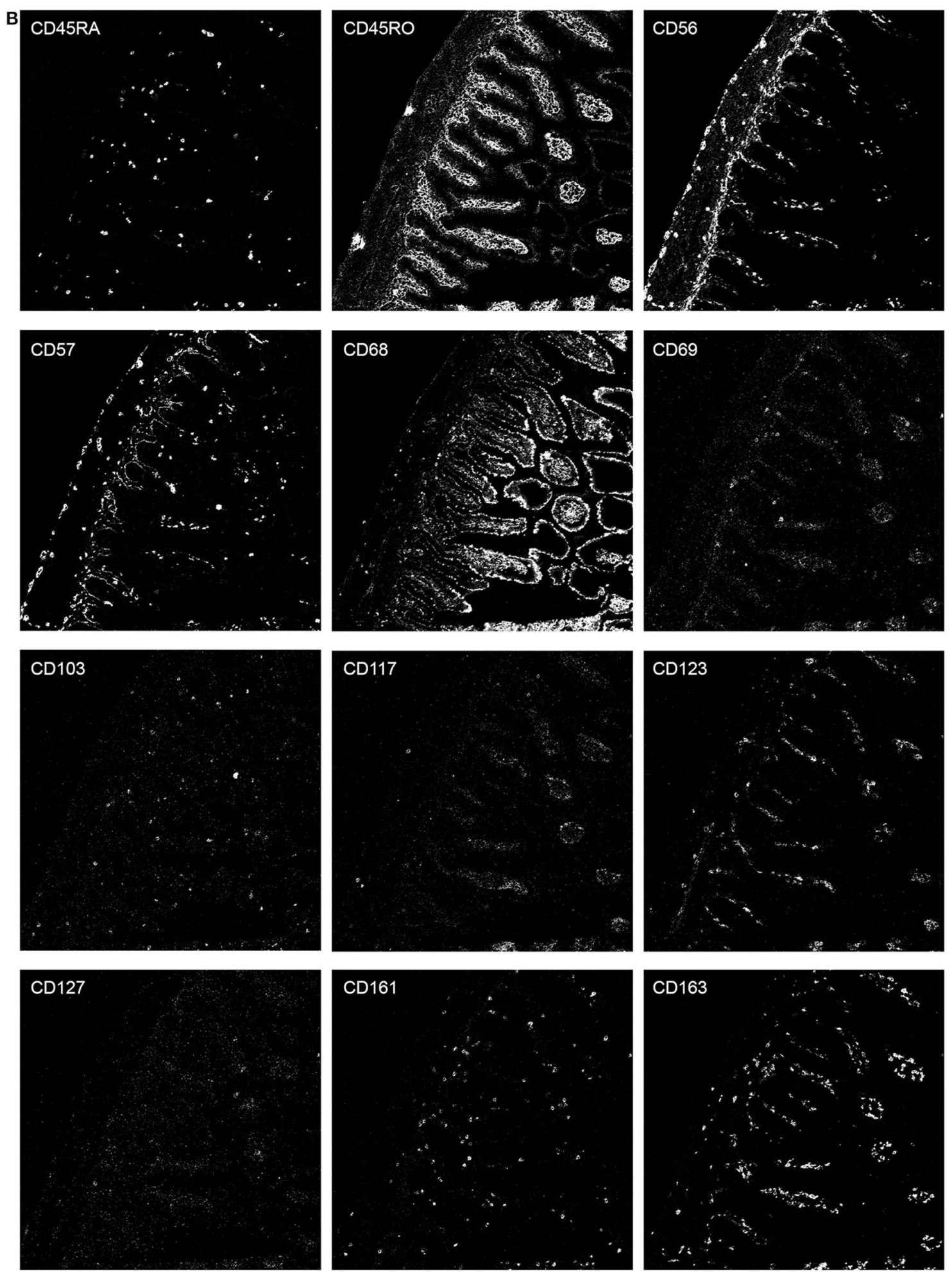

\section{CD161}

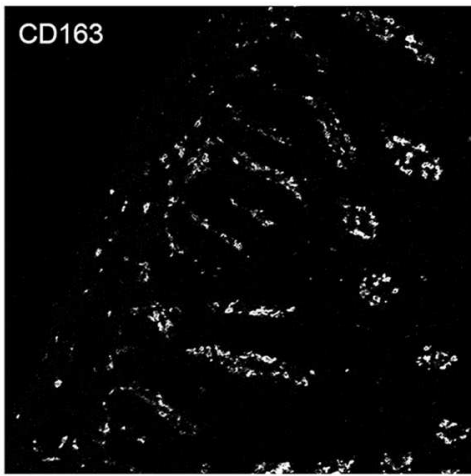

FIGURE 3 | Continued 

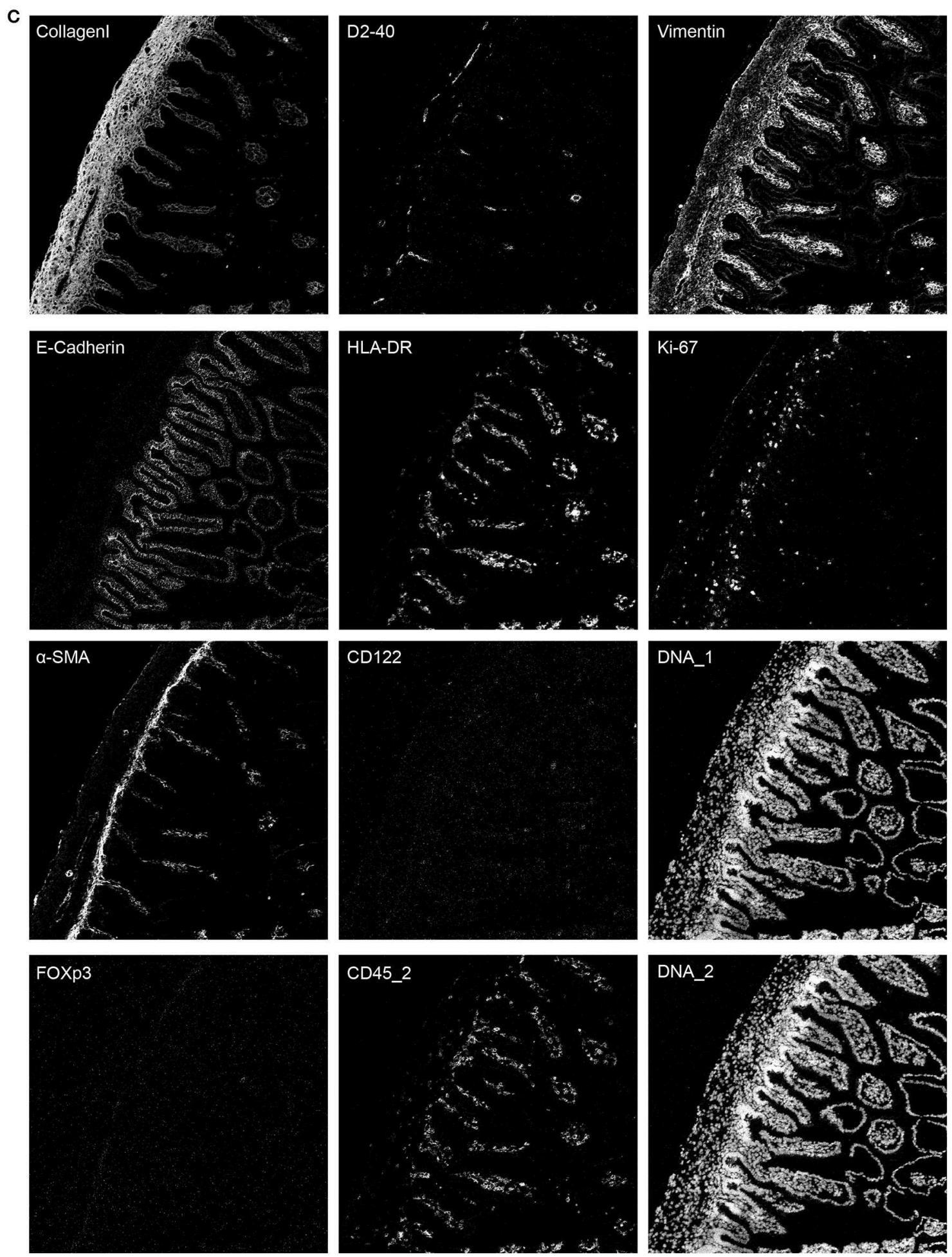

FIGURE 3 | (A-C) The optimized immunodetection of the 34-marker panel and nuclear staining in a single representative ROI for IMC on the human fetal intestine.

division (Ki-67), tissue-residency (CD103 and CD69), and expression of cytokine receptors (e.g., CD122 and CD127) (Figures 3A-C).
Based on the adjusted Threshold Min and default Threshold Max in the $\mathrm{MCD}^{\mathrm{TM}}$ viewer (Table 3), the resulting images were analyzed. Collagen I immunodetection was used to delineate 
TABLE 3 | The estimated signal-to- background ratio of the antibodies in the optimal staining protocol.

\begin{tabular}{|c|c|c|c|c|}
\hline Antigen & Channel & $\begin{array}{c}\text { Adjusted } \\
\text { threshold min }\end{array}$ & $\begin{array}{l}\text { Default } \\
\text { threshold max }\end{array}$ & $\begin{array}{c}\text { Estimated } \\
\text { signal-to-background } \\
\text { ratio* }\end{array}$ \\
\hline CD3 & $170 \mathrm{Er}$ & 1.00 & 17.94 & 17.94 \\
\hline CD4 & $145 \mathrm{Nd}$ & 1.50 & 5.41 & 3.61 \\
\hline CD5 & $160 \mathrm{Gd}$ & 1.50 & 4.17 & 2.78 \\
\hline CD7 & 153Eu & 1.50 & 21.97 & 14.65 \\
\hline CD8a & $146 \mathrm{Nd}$ & 1.50 & 4.60 & 3.07 \\
\hline CD11c & 162Dy & 1.00 & 4.42 & 4.42 \\
\hline CD20 & 161Dy & 2.00 & 5.08 & 2.54 \\
\hline CD27 & $167 \mathrm{Er}$ & 1.00 & 4.93 & 4.93 \\
\hline CD28 & $171 \mathrm{Yb}$ & 1.00 & 3.99 & 3.99 \\
\hline CD31 & $149 \mathrm{Sm}$ & 2.00 & 18.62 & 9.31 \\
\hline CD38 & $172 Y b$ & 1.50 & 12.01 & 8.01 \\
\hline CD45_1 & $89 Y$ & 1.50 & 9.66 & 6.44 \\
\hline CD45RA & 169Tm & 2.00 & 32.74 & 16.37 \\
\hline CD45RO & $173 \mathrm{Yb}$ & 3.00 & 17.60 & 5.87 \\
\hline CD56 & $176 \mathrm{Yb}$ & 5.00 & 61.80 & 12.36 \\
\hline CD57 & $174 \mathrm{Yb}$ & 5.00 & 22.25 & 4.45 \\
\hline CD68 & 159Tb & 5.00 & 66.47 & 13.29 \\
\hline CD69 & $144 \mathrm{Nd}$ & 1.50 & 4.20 & 2.80 \\
\hline CD103 & $155 \mathrm{Gd}$ & 1.50 & 4.16 & 2.77 \\
\hline CD117 & $165 \mathrm{Ho}$ & 1.00 & 4.58 & 4.58 \\
\hline CD123 & 151Eu & 1.50 & 6.46 & 4.31 \\
\hline CD127 & $156 \mathrm{Gd}$ & 2.00 & 4.32 & 2.16 \\
\hline CD161 & 164Dy & 1.50 & 7.42 & 4.95 \\
\hline CD163 & $154 \mathrm{Sm}$ & 2.00 & 23.10 & 11.55 \\
\hline Collagen I & $147 \mathrm{Sm}$ & 3.00 & 46.60 & 15.53 \\
\hline D2-40 & $115 \ln$ & 3.00 & 6.56 & 2.19 \\
\hline Vimentin & 175Lu & 5.00 & 94.23 & 18.85 \\
\hline E-Cadherin & $150 \mathrm{Nd}$ & 1.50 & 7.89 & 5.26 \\
\hline HLA-DR & $168 \mathrm{Er}$ & 3.00 & 41.36 & 13.79 \\
\hline $\mathrm{Ki}-67$ & $166 \mathrm{Er}$ & 2.00 & 11.69 & 5.85 \\
\hline$\alpha-\mathrm{SMA}$ & $148 \mathrm{Nd}$ & 3.00 & 46.20 & 15.40 \\
\hline CD122 & $158 \mathrm{Gd}$ & 1.00 & 3.48 & 3.48 \\
\hline DNA1 & $191 \mathrm{lr}$ & 3.00 & 44.85 & 14.95 \\
\hline FOXp3 & $142 \mathrm{Nd}$ & 2.00 & 3.10 & 1.55 \\
\hline CD45_2 & 163Dy & 2.00 & 14.10 & 7.05 \\
\hline DNA2 & 193Ir & 3.00 & 76.37 & 25.46 \\
\hline
\end{tabular}

*Estimated Signal-to-background was defined as Default Threshold Max/Adjusted Threshold Min.

the extracellular matrix of the basement membrane which exhibited the highest staining intensity (Figure 3C). Vessels with smooth muscle lining were detected by the presence of $\alpha$-smooth muscle actin ( $\alpha$-SMA, Figures 3C, 4A), and CD31 and D240 staining (Figures $\mathbf{3 A}, \mathbf{C}$ ). The epithelium and lamina propria were distinguished as Vimentin ${ }^{-}$E-Cadherin ${ }^{+}$and Vimentin ${ }^{+} \mathrm{E}-$ Cadherin $^{-}$, respectively (Figure 4A). Cells of hematopoietic origin were identified with an anti-CD45 specific antibody, revealing that the majority of the immune cells were localized in the lamina propria (Figure 3). To define the spatial distribution of different immune subsets in the human fetal intestine, $\mathrm{T}$ cells $\left(\mathrm{CD}^{+} \mathrm{CD}^{+}\right)$, innate lymphoid cells (ILCs, $\left.\mathrm{CD}^{-} \mathrm{CD}^{+}\right)$, B cells

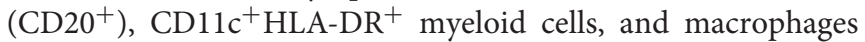
$\left(\mathrm{HLA}-\mathrm{DR}{ }^{+} \mathrm{CD}_{163}{ }^{+}\right.$), were identified and visualized in a single region of interest (Figures 4B,C). For comparison, the individual stains for DNA, the structural markers E-Cadherin, $\alpha$-SMA, and Vimentin, as well as the immune markers CD3, CD7, CD20, CD11c, HLA-DR, and CD163 are shown in Figure 4D. In Figure $4 \mathrm{~B}$ a single $\mathrm{CD} 20^{+} \mathrm{B}$ cells is identified (cyan) while $\mathrm{CD}^{+}{ }^{+} \mathrm{CD} 7^{+} \mathrm{T}$ cells (yellow) and $\mathrm{CD}^{-}{ }^{-} \mathrm{CD} 7^{+}$ILCs (green) are present both as isolated cells and adjacent to each other (two boxed areas on the left side of the image, Figure 4B). In addition, a white $\mathrm{CD} 11 \mathrm{c}^{+}$myeloid cells was detected colocalized with a $\mathrm{T}$ cell (boxed area on the right side of the image, Figure 4B). Moreover, the visualization of HLA-DR and CD163 reveals the close association of HLA-DR ${ }^{+} \mathrm{CD}_{163}{ }^{+}$macrophages (blue/cyan) with adjacent T cells and ILCs (two boxed area's on the left side of the image, Figure 4C), and several clusters of T cells and HLA$\mathrm{DR}^{+}$myeloid cells (Figure 4C). Thus, the optimized approach for snap-frozen tissue analysis with IMC presented here facilitates the simultaneous identification of multiple distinct cells types and distinct colocalization patterns thereof in a single image. In addition we applied the optimized staining protocol with the full antibody panel to two adult intestinal samples, one from a healthy control (Figure 5A) and another from a patient with inflammatory bowel disease (Figure 5B). Here we observed clear tissue structures based on E-Cadherin, $\alpha$-SMA, Vimentin, and DNA staining (Figure 5). Moreover, visualization of the immune lineage markers CD3, CD7, CD20, HLA-DR, CD163, and CD11c revealed the presence and distribution of lymphoid and myeloid immune cell subsets within the tissue context in a single section (Figure 5).

\section{DISCUSSION}

We report the development of a 34-antibody panel and an optimized staining protocol for snap-frozen tissue sections for analysis with IMC. Based on staining intensity and signal-tobackground ratio, we compared different fixation procedures, drying time of the tissue sections, and the impact of duration and temperature during the antibody incubation. In principle, IMC is applicable to both FFPE and snap-frozen tissue but most studies so far have used FFPE tissue. In contrast to FFPE, snap-frozen tissue samples do not require antigen retrieval, thus simplifying the immunodetection protocol. Moreover, antibodies that can be used with frozen tissue cannot always be employed with FFPE tissue and vice versa. Thus, it is useful to have both options available. Previously, Chang et al. (14) have shown that acetone can be used for the fixation of frozen and FFPE tissue for IMC. However, while we also observed that acetone fixation can be used, the low quality DNA staining did not allow an optimal cell segmentation analysis. Therefore, we compared several fixation procedures that identified methanol or a combination of $1 \%$ PFA and methanol as appropriate for snap-frozen samples. While the tested variations in drying condition of the tissue samples did not influence the outcome of the staining procedure, we 
A

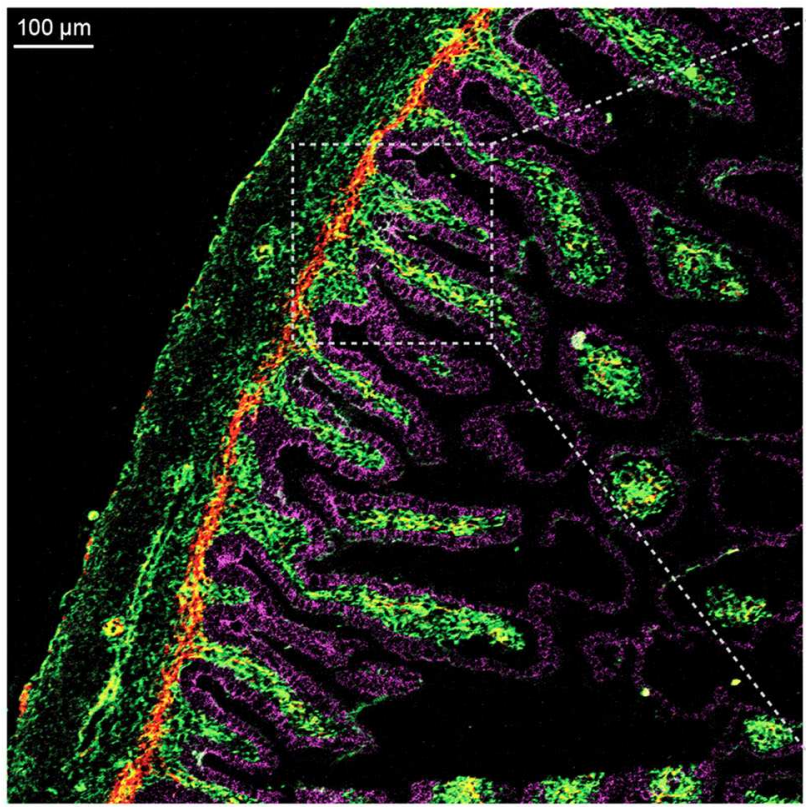

E-Cadherin a-SMA Vimentin
B

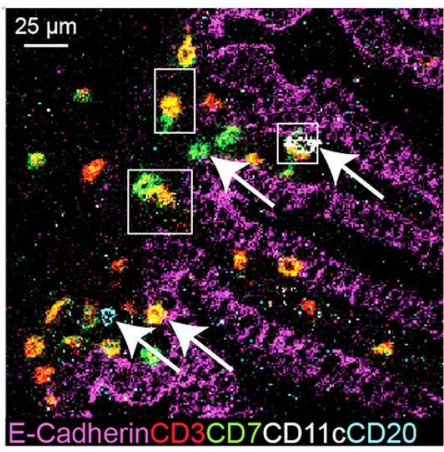

C

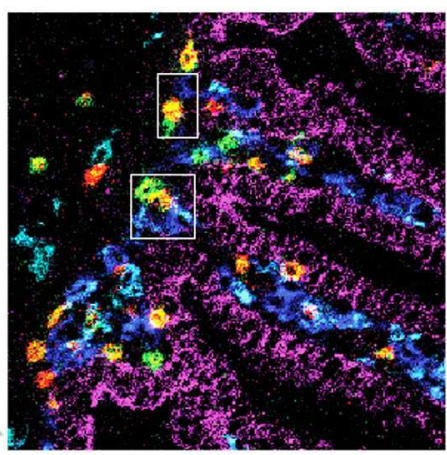

E-CadherinCD3CD7HLA-DR
D

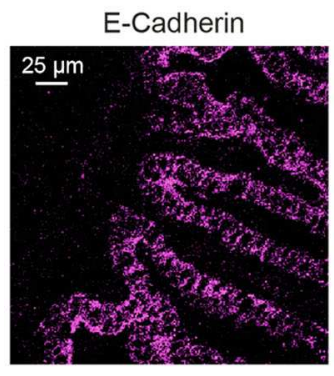

CD11C

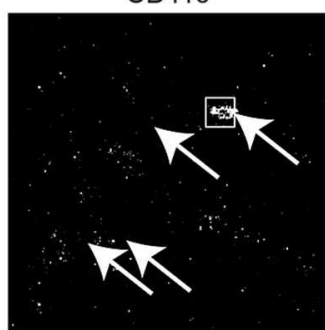

a-SMA

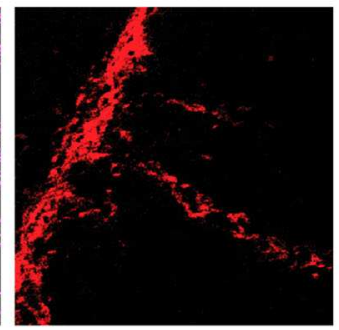

CD20

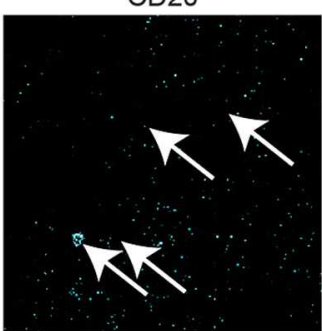

Vimentin

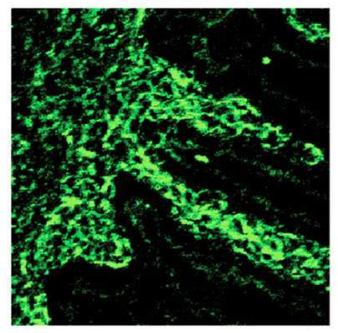

HLA-DR

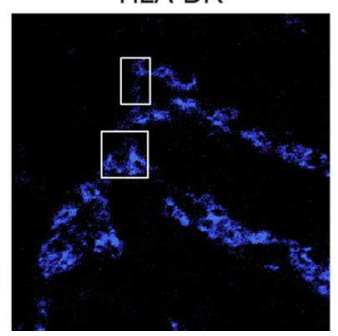

CD3

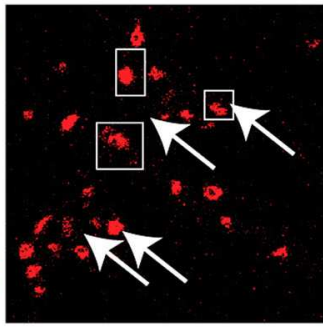

CD163

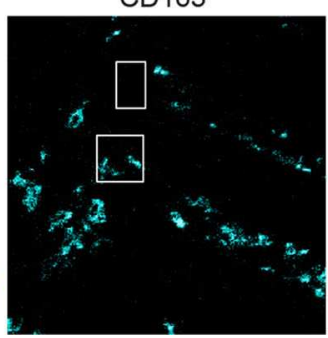

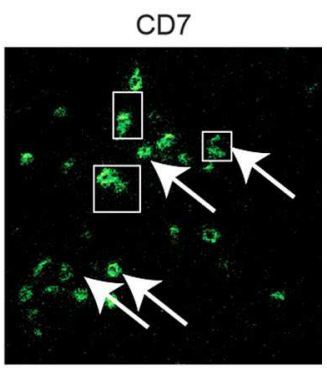

DNA

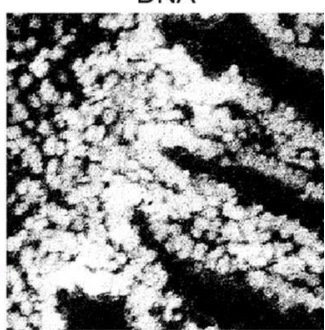

FIGURE 4 | Visualization of the tissue structure and detection of immune cell types in a single region of interest in the human fetal intestine by IMC. (A) Representative mass cytometry image of the fetal intestine showing the overlay of E-Cadherin (magenta), Vimentin (green), and $\alpha$-SMA (red). (B-D) Identification of immune cell subsets. (B) T cells $\left(\mathrm{CD}^{+} \mathrm{CD} 7^{+}\right)$, innate lymphoid cells (ILCs, $\left.\mathrm{CD} 3^{+} \mathrm{CD} 7^{-}\right)$and $\mathrm{B}$ cells $\left(\mathrm{CD} 2 \mathrm{O}^{+}\right)$; (C) myeloid cell $\left(\mathrm{CD} 11 \mathrm{C}^{+}\right)$and macrophages $\left(\mathrm{HLA}-\mathrm{DR}{ }^{+} \mathrm{CD} 163^{+}\right)$. The arrows indicate different immune cell types, while the boxes indicate the interaction between ILCs, T cells, and myeloid cells. (D) Individual antibody stains.

observed that antibody incubation overnight at $4^{\circ} \mathrm{C}$ yielded optimal results.

We applied the 34-antibody panel to identify various stromal elements and a variety of immune cell subsets in the human fetal intestine. The localization of collagen I, Vimentin, E-Cadherin and $\alpha$-SMA allowed the visualization of the major architecture of the tissue sample and distinction of the villi, crypts, basal membrane and lamina propria. Simultaneously, T cells, ILCs, and various myeloid cell subsets could be identified as well as interactions between these cell types individually and in clusters 


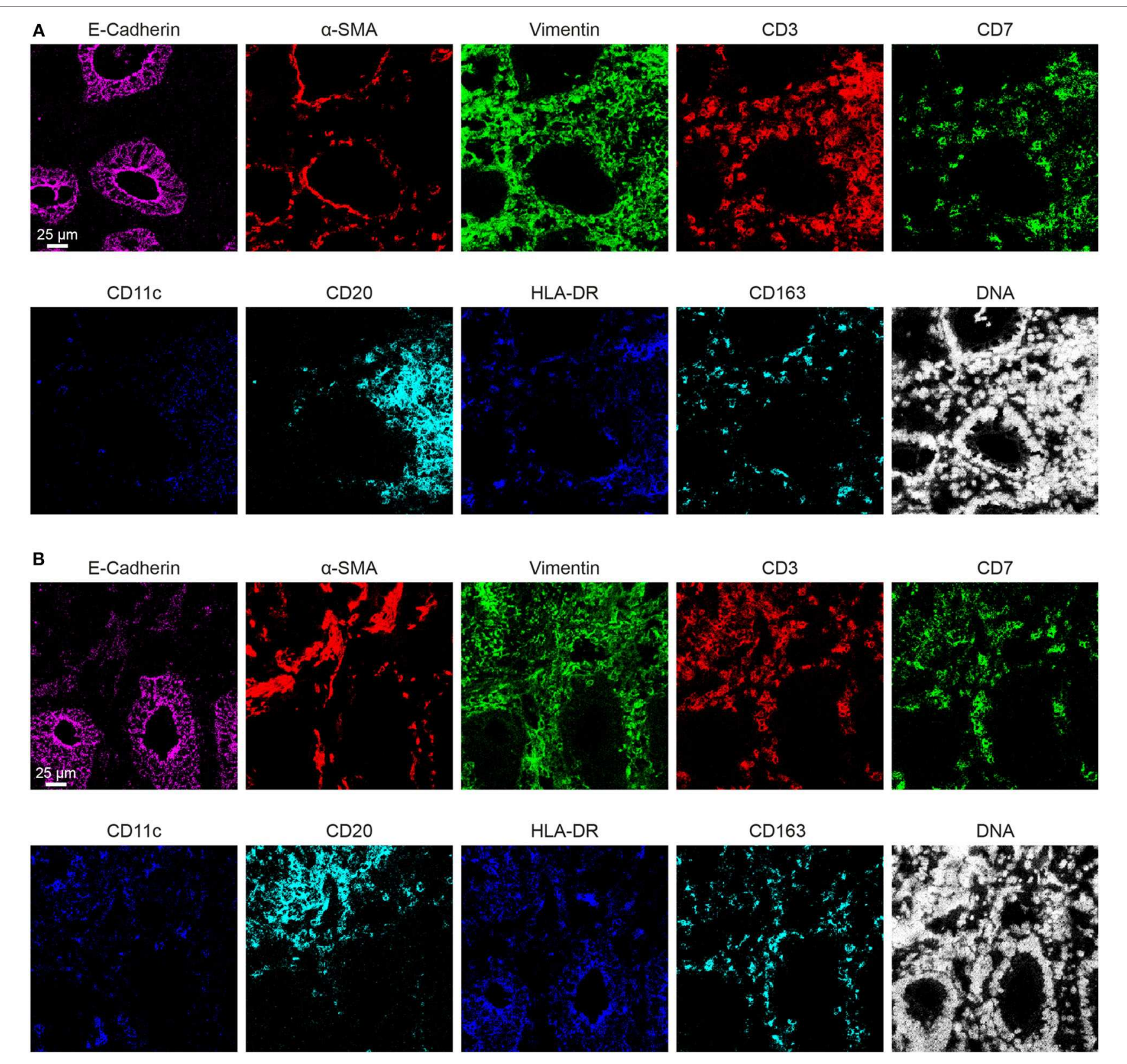

FIGURE 5 | Representative mass cytometry images of 2 adult intestines. (A) The adult intestinal sample from a healthy control. (B) The adult intestinal sample from a patient with inflammatory bowel disease.

of lymphoid and myeloid cells. Here, the specific co-localization of ILCs, T cells, and myeloid cells in the lamina propria suggests that the ILC may somehow modulate the interaction between the $\mathrm{T}$ cells and myeloid cells directly. Moreover, recent findings have shown that memory $\mathrm{T}$ cells are generated in the human fetal intestine and the specific co-localization of $\mathrm{T}$ cells and myeloid cells may ultimately reveal where such memory responses are initiated (16). Here, additional markers in the antibody panel, like HLA-DR and Ki-67, will likely aid in the identification of activated $\mathrm{T}$ cells in situ.

In the present study we have used the $\mathrm{MCD}^{\mathrm{TM}}$ viewer software to visualize the images of the tissue sections. In addition cell segmentation approaches based on the identification of nuclei have been developed to aid in the visualization of IMC data $(17,18)$ as well as computational approaches to identify and quantify cell-cell interactions like Imacyte and Histocat $(19,20)$. Together this allows for an in depth investigation of cellular interactions in a variety of tissues. Thus, IMC offers a major advantage over classical immunohistochemistry techniques which are limited by the numbers of markers that can be included simultaneously. Together with other studies that have developed antibody panels for FFPE tissue $(15,21,22)$ this sets the stage for detailed studies to determine immune heterogeneity and cell-cell interactions in situ, providing a novel 
layer of understanding of functioning of the immune system on tissues. We anticipate that our study will guide other researchers that wish to use IMC for analysis of tissue of choice. Here the conditions defined in the present study can be used as a starting point, however, we like to emphasize that every tissue has its own characteristics that may require further optimization for the tissue under investigation.

\section{DATA AVAILABILITY STATEMENT}

All datasets presented in this study are included in the article/Supplementary Material.

\section{ETHICS STATEMENT}

The studies involving human participants were reviewed and approved by Leiden University Medical Center_LUMC (Protocol P08.087). The patients/participants provided their written informed consent to participate in this study. Written informed consent was obtained from the individual(s) for the publication of any potentially identifiable images or data included in this article.

\section{AUTHOR CONTRIBUTIONS}

NG, NL, and FK conceived the study and wrote the manuscript. NG performed most experiments with the help of VU. NG

\section{REFERENCES}

1. Li N, van Unen V, Hollt T, Thompson A, van Bergen J, Pezzotti N, et al. Mass cytometry reveals innate lymphoid cell differentiation pathways in the human fetal intestine. J Exp Med. (2018) 215:1383-96. doi: 10.1084/jem.201 71934

2. de Vries NL, van Unen V, Ijsselsteijn ME, Abdelaal T, van der Breggen R, Farina Sarasqueta A, et al. High-dimensional cytometric analysis of colorectal cancer reveals novel mediators of antitumour immunity. Gut. (2020) 69:691703. doi: 10.1136/gutjnl-2019-318672

3. Havel JJ, Chowell D, Chan TA. The evolving landscape of biomarkers for checkpoint inhibitor immunotherapy. Nat Rev Cancer. (2019) 19:133-50. doi: 10.1038/s41568-019-0116-x

4. Chang Q, Ornatsky OI, Siddiqui I, Loboda A, Baranov VI, Hedley DW. Imaging mass cytometry. Cytometry A. (2017) 91:160-9. doi: $10.1002 /$ cyto.a.23053

5. Lichtman JW, Conchello JA. Fluorescence microscopy. Nat Methods. (2005) 2:910-9. doi: 10.1038/nmeth817

6. Davis AS, Richter A, Becker S, Moyer JE, Sandouk A, Skinner J, et al. Characterizing and diminishing autofluorescence in formalin-fixed paraffinembedded human respiratory tissue. J Histochem Cytochem. (2014) 62:405-23. doi: 10.1369/0022155414531549

7. Giesen C, Wang HA, Schapiro D, Zivanovic N, Jacobs A, Hattendorf B, et al. Highly multiplexed imaging of tumor tissues with subcellular resolution by mass cytometry. Nat Methods. (2014) 11:417-22. doi: 10.1038/nmeth.2869

8. Bandura DR, Baranov VI, Ornatsky OI, Antonov A, Kinach R, Lou XD, et al. Mass cytometry: technique for real time single cell multitarget immunoassay based on inductively coupled plasma time-of-flight mass spectrometry. Anal Chem. (2009) 81:6813-22. doi: 10.1021/ac901049w

9. Chevrier S, Crowell HL, Zanotelli VRT, Engler S, Robinson MD, Bodenmiller B. Compensation of signal spillover in suspension and imaging mass cytometry. Cell Syst. (2018) 6:612-620.e5. doi: 10.1016/j.cels.2018.02.010 performed most of the analyses with the help of VU, MI, LO, AM, and NM. SC provided human fetal tissues. All authors discussed the results and commented on the manuscript.

\section{FUNDING}

This research was supported by Leiden University Medical Center (NG, VU, MI, LO, AM, SC, NM, FK, and NL), and the China Scholarship Council (NG and NL). FK was supported by the collaboration project TIMID (LSHM18057-SGF) financed by the PPP allowance made available by Top Sector Life Sciences \& Health to Samenwerkende Gezondheidsfondsen (SGF) to stimulate public-private partnerships and co-financing by health foundations that are part of the SGF.

\section{ACKNOWLEDGMENTS}

We thank the Center for Contraception, Abortion and Sexuality (Leiden and The Hague) for collection and provision of fetal material, K. Lodder, T. van Herwaarden, M. Bialecka, and F. Wang for dissection of fetal tissues.

\section{SUPPLEMENTARY MATERIAL}

The Supplementary Material for this article can be found online at: https://www.frontiersin.org/articles/10.3389/fimmu. 2020.01466/full\#supplementary-material
10. Damond N, Engler S, Zanotelli VRT, Schapiro D, Wasserfall CH, Kusmartseva I, et al. A map of human type 1 diabetes progression by imaging mass cytometry. Cell Metab. (2019) 29:755-768.e5. doi: 10.1016/j.cmet.2018.11.014

11. Wang YJ, Traum D, Schug J, Gao L, Liu CY, Atkinson MA, et al. Multiplexed in situ imaging mass cytometry analysis of the human endocrine pancreas and immune system in type 1 diabetes. Cell Metab. (2019) 29:769-783.e4. doi: 10.1016/j.cmet.2019.01.003

12. Li N, van Unen V, Abdelaal T, Guo N, Kasatskaya SA, Ladell K, et al. Memory CD4(+) $\mathrm{T}$ cells are generated in the human fetal intestine. Nat Immunol. (2019) 20:301-12. doi: 10.1038/s41590-018-0294-9

13. Li N, van Unen V, Guo N, Abdelaal T, Somarakis A, Eggermont J, et al. Earlylife compartmentalization of immune cells in human fetal tissues revealed by high-dimensional mass cytometry. Front Immunol. (2019) 10:1932. doi: 10.3389/fimmu.2019.01932

14. Chang Q, Ornatsky O, Hedley D. Staining of frozen and formalinfixed, paraffin-embedded tissues with metal-labeled antibodies for imaging mass cytometry analysis. Curr Protoc Cytom. (2017) 82:12471-8. doi: $10.1002 /$ cpcy.29

15. Ijsselsteijn ME, van der Breggen $R$, Sarasqueta AF, Koning F, de Miranda NFCC. A 40-marker panel for high dimensional characterization of cancer immune microenvironments by imaging mass cytometry. Front Immunol. (2019) 10:2534. doi: 10.3389/fimmu.2019.02534

16. Li N, van Unen V, Abdelaal T, Guo NN, Kasatskaya SA, Ladell K, et al. Memory CD4(+) $\mathrm{T}$ cells are generated in the human fetal intestine. Nat Immunol. (2019) 20:301-12. doi: 10.1038/s41590-018-0294-9

17. Sommer C, Straehle C, Kothe U, Hamprecht FA. In: Ieee International Symposium on Biomedical Imaging: From Nano to Macro I. Ilastik: Interactive learning and segmentation toolkit. IEEE Comput Soc Conf Comput Vis Pattern Recogn Proceedings - International Symposium on Biomedical Imaging in Chicago (2011). p. 230-3.

18. Jones TR, Kang IH, Wheeler DB, Lindquist RA, Papallo A, Sabatini $\mathrm{DM}$, et al. CellProfiler analyst: data exploration and analysis software 
for complex image-based screens. BMC Bioinformatics. (2008) 9:482. doi: 10.1186/1471-2105-9-482

19. Somarakis A, Van Unen V, Koning F, Lelieveldt BPF, Hollt T. ImaCytE: Visual exploration of cellular microenvironments for imaging mass cytometry data. IEEE Trans Vis Comput Graph. (2019) 1-1. doi: 10.1109/TVCG.2019.2931299

20. Schapiro D, Jackson HW, Raghuraman S, Fischer JR, Zanotelli VRT, Schulz D, et al. histoCAT: analysis of cell phenotypes and interactions in multiplex image cytometry data. Nat Methods. (2017) 14:873-6. doi: 10.1038/nmeth.4391

21. Carvajal-Hausdorf DE, Patsenker J, Stanton KP, Villarroel-Espindola F, Esch A, Montgomery RR, et al. Multiplexed (18-Plex) measurement of signaling targets and cytotoxic $\mathrm{T}$ cells in trastuzumab-treated patients using imaging mass cytometry. Clin Cancer Res. (2019) 25:3054-62. doi: 10.1158/1078-0432.CCR-18-2599

22. Singh N, Avigan ZM, Kliegel JA, Shuch BM, Montgomery RR, Moeckel GW, et al. Development of a 2-dimensional atlas of the human kidney with imaging mass cytometry. JCI Insight. (2019) 4:e129477. doi: 10.1172/jci.insight.1 29477

Conflict of Interest: The authors declare that the research was conducted in the absence of any commercial or financial relationships that could be construed as a potential conflict of interest.

Copyright $(2020$ Guo, van Unen, Ijsselsteijn, Ouboter, van der Meulen, Chuva de Sousa Lopes, de Miranda, Koning and Li. This is an open-access article distributed under the terms of the Creative Commons Attribution License (CC BY). The use, distribution or reproduction in other forums is permitted, provided the original author(s) and the copyright owner(s) are credited and that the original publication in this journal is cited, in accordance with accepted academic practice. No use, distribution or reproduction is permitted which does not comply with these terms. 